doi $10.15826 /$ recon.2021.7.2.009

UDC 332.1, 504.4.062.2

JEL Q25, R58

\title{
Program-modular approach to the coordination of interests of participants of regional water markets (the case of southern regions of Russia)
}

\author{
L.G. Matveeva ${ }^{1,2}$, O.A. Chernova ${ }^{1,2} \bowtie$, E.V. Kaplyuk ${ }^{1}$ \\ ${ }^{1}$ Southern Federal University, Rostov-on-Don, Russia; chernova.olga71@yandex.ru \\ ${ }^{2}$ Russian Information, Analytical and Scientific Research Water Management Center, Rostov-on-Don, Russia
}

\begin{abstract}
Relevance. The efficiency of water management is determined by the quality of managerial decision-making. These decisions should ensure the balance of interests of all the actors in regional water markets. At present, in Russia, however, the balance of interests is considered only in macro-level strategies, which leads to the inefficiency of water distribution in regions. The study of the issues of rational distribution of water resources and their use in various industries and spheres of activity is, therefore, particularly relevant. Research objective. This article aims to propose methodology for maintaining the optimal balance between the interests of economic actors in regional water markets. Data and methods. This article proposes a program-modular approach to building a more efficient water management system. It is shown how the proposed methodology based on the incremental model of management can be used for balancing the interests of economic agents (suppliers and consumers of water resources). Results. It is proved that the plurality and divergence of interests of economic agents makes it difficult to manage them and thus precludes social and economic development of territories. The structural-functional analysis of the incremental model reveals various types of connections between the water-retaining capacity of gross regional product and indexes of industrial production for regions of the South Federal District. Conclusions. The prospects of development of water management in regions are associated with ensuring the balance of interests of the water market's participants. The program-modular approach proposed by the authors combines the administrative and resource potential of regional water management and aligns the goals on the regional level with the more general goals of hydropower modernization. The novelty of our research is that it relies on the incremental model, which, unlike other models of management, leads to an incremental achievement of the desired through certain iterations.
\end{abstract}

\section{KEY WORDS}

regional water management, program-modular approach, incremental model, architectonics, balance of interests

\section{FOR CITATION}

Matveeva, L.G., Chernova, O.A., Kaplyuk, E.V. (2021) Programmodular approach to the coordination of interests of participants of regional water markets (the case of southern regions of Russia). R-economy, 7(2), 100-110. doi: 10.15826/ recon.2021.7.2.009

\section{Программно-модульный подход к координации интересов участников региональных водных рынков (на примере южных регионов России)}

\author{
Л.Г. Матвеева ${ }^{1,2}$, О.А. Чернова ${ }^{1,2} \bowtie$, Е. В. Каплюк ${ }^{1}$ \\ ${ }^{1}$ Южный федеральный университет, Ростов-на-Дону, Россия; chernova.olga71@yandex.ru \\ ${ }^{2}$ Российский информационно-аналитический и научно-исследовательский водохозяйственный иентр, \\ Ростов-на-Дону, Россия
}

\section{АННОТАЦИЯ}

Актуальность. Эффективность развития водного хозяйства определяется качеством принимаемых управленческих решений, которые должны обеспечивать баланс интересов всех субъектов рынка водных ресурсов. В России в настоящее время вопросы соблюдения баланса интересов рассматривается только на макроуровне. В результате структура распределения водных ресурсов в регионах является неэффективной. Это делает актуальным исследование вопросов рационального распределения водных ресурсов как фактора производства с позиций эффективности их

\section{КЛЮЧЕВЫЕ СЛОВА}

региональное управление водными ресурсами, программно-модульный подход, инкрементная модель, архитектоника, баланс интересов 
использования в различных отраслях и сферах деятельности. Цель исследования. Цель статьи - предложить способ и инструментарий формирования системы балансовых отношений между экономическими субъектами ВХК региона. Данные и методы. В данной статье предлагается программно-модульный подход к построению более эффективной системы управления водными ресурсами. Показано, как предложенная методология, основанная на инкрементной модели управления, может быть использована для обеспечения баланса интересов экономических агентов (поставщиков и потребителей водных ресурсов). Результаты. Доказано, что множественность и разнонаправленность интересов субъектов одного водного бассейна является причиной дисбаланса и низкой синергии их взаимодействий, что негативно сказывается не только на функционировании региональной водной системы, но и на показателях социально - экономического развития территорий. Структурно-функциональный анализ предложенной авторами инкрементальной модели управления позволил выявить различные типы связей между уровнем водоемкости валового регионального продукта и индексами промышленного производства для регионов Юга России. Выводы. Перспективы развития водного хозяйства региона во многом определяются обеспечением баланса интересов участников рынка водных ресурсов. Предлагаемый авторами программно-модульный подход к решению этой задачи позволяет объединить административно-ресурсный потенциал водохозяйственного комплекса в рамках общей стратегии модернизации гидроэнергетики. Новизна исследования заключается в том, что в отличие от существующих моделей управления инкрементная модель дает возможность получить инкрементный прирост достижения цели согласования интересов участников водохозяйственного комплекса путем реализации определенного набора итераций.

\section{ДЛЯ ЦИТИРОВАНИЯ}

Matveeva, L.G., Chernova, O.A., Kaplyuk, E.V. (2021) Programmodular approach to the coordination of interests of participants of regional water markets (the case of southern regions of Russia). R-economy, 7(2), 100-110. doi: 10.15826/ recon.2021.7.2.009

\section{Introduction}

In modern conditions, successful development of the water industry in Russia is determined by the quality of managerial decisions that would ensure the generation of significant positive effects at all levels of management. At the same time, these decisions should take into account the economic, political, and social interests of players in the water resources market. The challenge to balance hydropower subjects of interest in the new model of Russia's development involves the implementation of the theoretical and applied approaches. These approaches should be adapted to the properties and peculiarities of the functioning of water management complexes (WCC) in the regions. These approaches should take into account not only the diverse interests of economic entities, but also the existing structure of the region's hydropower sector.

In recent years, a more focused, program-modular approach has been widely applied in the sphere of strategic management. This approach helps mobilize both internal and external resources for self-organization and self-regulation of systems at various levels. Among the numerous advantages of this approach, it enables regional governments to concentrate their resources on top priority problems; increase the sense of responsibility of those in charge of the program implementation; set specific goals and timeframes for more efficient program implementation, and so on (Delorit et al., 2019; Idziev, 2011; Kosolapov et al., 2018; Matchaya et al., 2019; Matveeva et al., 2018; Mitrofanova, 2006, Nikitaeva \& Aleshin, 2013; Hmaed et al., 2019; Polyakova \& Shevchenko, 2017; and others).

The success of reforms in hydropower industry depends on the formation of effective mechanisms to maximize the interests of all categories of participants in the water market. Unfortunately, at the moment, there is a perceivable lack of such mechanisms in Russia. The balance of interests is considered only on the macrolevel, while for regional water markets only the general trends in the institutional environment are taken into account. Research literature, in its turn, also fails to provide any models that would take into account the interests of participants in these markets. Different models of water markets (Levit-Gurevich et al, 2010; Xu, Singh, 2004; Loukas, Milopolos, Vasiliades, 2007; Torregrosa, Sevilla, Montaño, López-Vico, 2010; Nazemi et a. 2020; Suratin et al. 2019), developed to justify the "fair" prices in practice, do not address the problem of how the strategic interests of players should be linked. 
There is a large body of research dealing with rational distribution of water resources as a factor of production in various industries and spheres (Calizayar, Meixner et al. 2010; Danyang et al. 2020; Matveeva et al. 2020; Niua, Li et al. 2016; Zhang, Guo, 2016). Nevertheless, the structure of water distribution in Russian regions is unable to ensure the growth of GRP. Among the factors that may contribute to the system's efficiency is the positive synergy of the multidirectional interests of all participants in the water sector. This is the research gap that our paper seeks to address.

The objective of the article is to propose methodology for maintaining balanced relations between the economic actors in the regional water market. This purpose determined the following research tasks: first, consider the possibility of applying the program-modular approach for managing the strategic development of the hydropower sector; second, build an incremental management model that would enable more coordinated interactions of participants in regional water markets; and, finally, analyze the case of regions in the Southern Federal District of Russia to demonstrate the potential of the proposed methodology.

\section{Material and Method}

The program-modular approach described in this study is based on the convergence of several methodological approaches corresponding to the characteristics of the manageable socio-economic system. The program-modular approach allows for the interconnection and integrated use of individual techniques and methods, mechanisms and tools for making and implementing managerial decisions to solve the problem of ensuring a balance of interests. The program-modular approach is based on structuring of the controlled system by dividing it into hierarchical components relatively independent subsystems of controlled (or adjustable) modules. These modules can be managed through program activities of various scale. How detailed the description of these hierarchies is depends on the objectives, the sphere of application and the level of administrative decision-making. The modules can be focused on various aspects of the water market. Thus, administrative and resource potential can be combined in order to modernize the hydropower infrastructure across the region.

Regional programs are part of federal programs and, therefore, they actualize the more general schemes and programs of development by taking into account regional factors of development. In their turn, programs and investment projects of specific enterprises and companies highlight regional priorities of development, and their purposes and tasks fit into those described in programs and strategies of regional and federal levels. Our research evidence demonstrates that the significant differentiation of forms, methods and technologies of management in the hydropower sector creates certain difficulties in the coordination of separate plans and meeting the needs of economic agents.

The resulting issues can be divided into several groups:

1) the low degree of coherence between the goals, tasks, mechanisms and tools at the different levels of management. This, in turn, precludes the achievement of a synergetic effect that would have been possible otherwise;

2) the low efficiency of mechanisms for attraction of internal and external investment into hydropower modernization projects;

3) insufficient regulation of the seller-buyer relationship has a direct and indirect influence on the degree to which the interests of participants of the water market are met.

To solve the above-mentioned problems, it is first and foremost necessary to ensure the coherence of the programs and strategies on different levels. The programs for specific regions and enterprises, in their turn, should be tailored to fit the specific needs of the region, its hydropower sector and the capacity of its water basin.

Since the market of water resources as a complex system with a hierarchy of economic agents, it is appropriate "to consider such economic system as the object of management consisting of a set of modules" (Shevchenko, 2009). This way we can present the configuration of the control system for development of the hydropower sector as a set of separate blocks - programs which adjust administrative influences to the changing external environment.

Let us now consider some aspects of the program-modular approach in the context of strategic development of hydropower. In this respect what comes to the fore is the development of adequate tools to measure the balance of interests and expectations of regional market participants by taking into account national strategic plans in this sphere. To build a system of synergetic relations between the participants of a water market 
and maintain the balance of their interests, it is necessary to use mutually acceptable water prices ("expenses plus" model).

To a certain extent, the "expenses plus" model may help balance the interests of suppliers and consumers of water resources, but only in a shortterm period. From the strategic perspective, it is necessary to improve the this model and include such groups of participants as consumers (individual consumers and legal entities) and enterprises. Participants of each group have their own interests, which sometimes contradict those of other players. In Russia the system of guaranteed water supply to consumers forms a basis for the development of mechanisms of ensuring the balance of such interests.

As far as the interests (expectations) of the population are concerned, most economists (e.g. Tikhomirova \& Vinogradov, 2007) pay attention to the influence of the water prices on their welfare, with welfare understood in its narrow meaning and measured through such indicators as consumer income and expenditures. Therefore, the interests of the population are expressed in such terms as differentiated water tariffs, specific weight of the costs of water in the total value of consumer spending (Tikhomirova \& Vinogradov, 2007). The second major condition for ensuring that the population's needs in water are satisfied is the reliability of the water supply system. The level of water prices determines people's economic behavior. The problem lies in the fact that analysis of how well the interests of all the actors - government, water supplies, businesses and population - are met should take into account a whole complex of objective factors. Indicators should be chosen depending on the availability of official data. The analysis should also take into consideration how aware local people are of the key characteristics of the water supply system that they comfort depends on.

Certainly, the water-retaining capacity of domestic production is connected not only to the water prices but also to the rationality of water use. The water-retaining capacity of production to a large extent determines how attractive is this or that enterprise for investors. In particular, enterprises which use less expensive water-conservation technologies are more attractive for investors, that is, the point of the matter lies not only in the more economical use of water resources but also in the possibility to increase the outputs while keeping the costs of water at the same level. Thus, the indicator of water consumption of this or that enterprise should take into account its potential for more rational water use (e.g. through the use of water-saving technologies). In other words, the use of innovative technologies to reduce, reuse, and recycle water is in the interests of industrial enterprises themselves. Nevertheless, Russian enterprises are still behind their Western counterparts in this sphere. This can be explained not only by the lack of relevant technologies and technical solutions, but also by the inefficiency of the existing financial and economic mechanisms that are supposed to stimulate the effort for more rational water use in production. Speaking about quality of water supply, it should be noted that it determines the continuity and efficiency of production since failures in water supply can cause disruptions in production and other emergencies. To this end, customer-oriented programs can be recommended.

Originally, the incremental approach was offered by Charles Lindblom (1959) for company management, but then it was widely adopted for systems of decision-making support. We believe that the system for ensuring coordinated interaction of participants of the water market based on the principles of incrementalism could prove to be effective on all levels of water management.

Figure 1 illustrates how the incremental model can be applied in the hydropower sector in regions of the Southern Federal District of Russia. It shows that the incremental model consists of the management, objects of management, consumers of water resources and research institutions.

Considering the interests of water suppliers, it is important to remember that the lack of innovation in this sphere impedes not only the development of regional water supply systems but also the regions' overall economic growth. Innovative projects will enable regional governments to minimize the costs of production and distribution of water between the consumers, to stimulate rational use of water resources, and reduce the accident rate of production, improve water quality, environmental sustainability and so on. To make innovation projects more attractive for regional enterprises participating in the water market, such projects should meet the criteria of cost efficiency.

Another important point to consider is how water losses are estimated and how they affect water prices. Normally, water losses are included in water tariff calculations. Moreover, there are water losses of companies and water losses caused by measurement errors. Companies are obliged to use their revenue to cover their water losses. 
In the development of national economy, including regional interests, the development of the hydropower sector is the most essential since this sector plays the key role in the socio-economic development of regions. Since the development of national (and regional) economies is directly determined not only by the volume but also the nature of water consumption, it is necessary to introduce an indicator reflecting the interests of the state in this sphere. Another important indicator reflecting the state (regional) interests connected with the price of water is the influence of water supply on the social sphere.

Figure 2 illustrates how the interests of economic agents in the regional water market can be balanced with the help of mutually acceptable pricing of water. Therefore, the proposed method has a socio-economic nature as it takes into ac- count the existing structure of the water management system in the concrete basin since it is this structure that determines the relationships between the market participants.

The incremental model provides the most effective tool for balancing the interests of participants of a regional water market.

\section{Results}

The Southern Federal District comprises four water basins: Donskoy, Kuban, Western Caspian and Lower Volga. Therefore, the architectonics of the water management complex of the Southern Federal District includes many objects (reservoirs, hydro-structures, etc.) and is subject to multi-institutional regulation. It is necessary to harmonize the regulations in the framework of interdepartmental coordination.

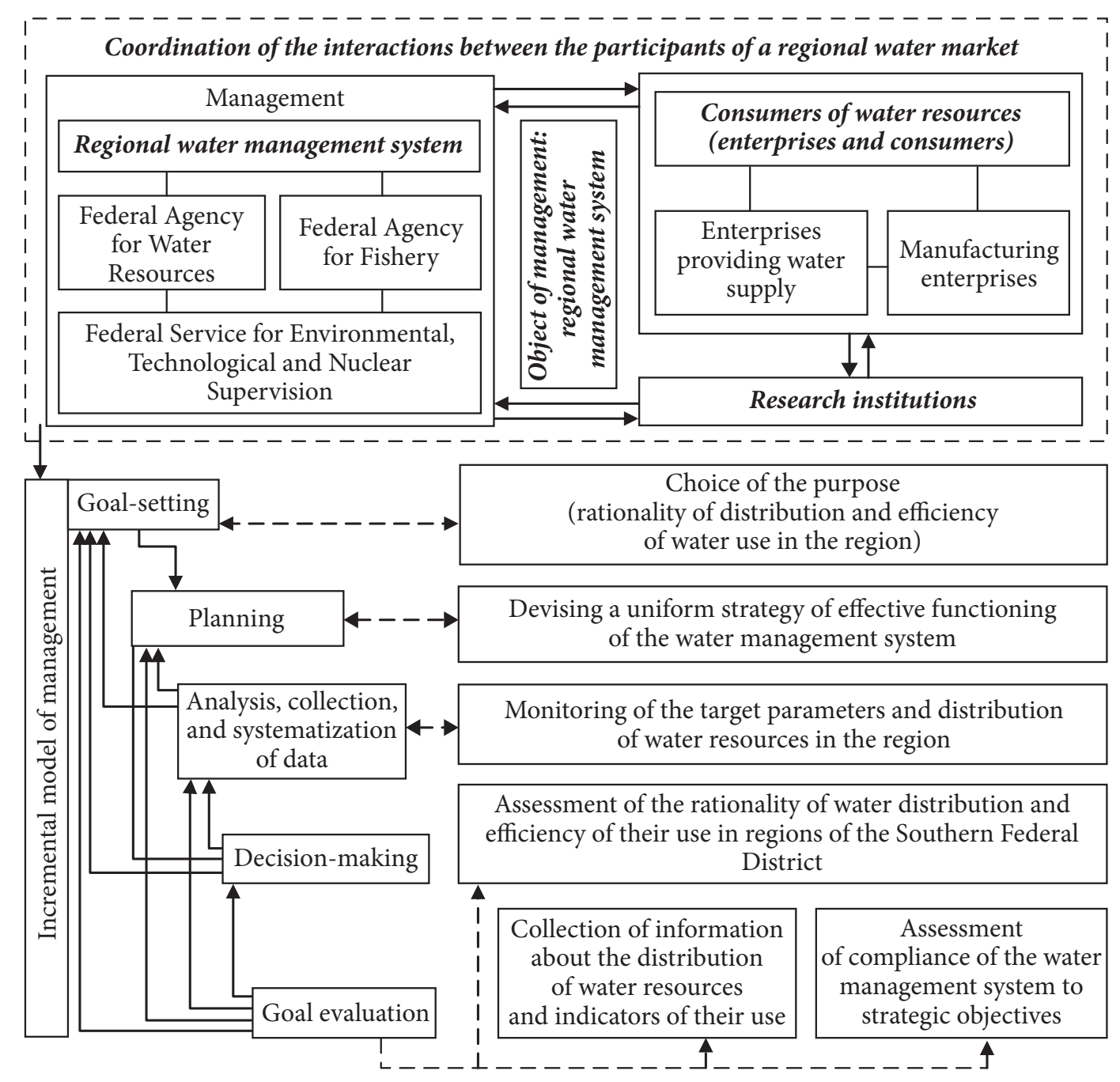

Figure 1. Incremental model of management of the coordinated interaction of participants of a regional water management complex

Source: Compiled by the authors 


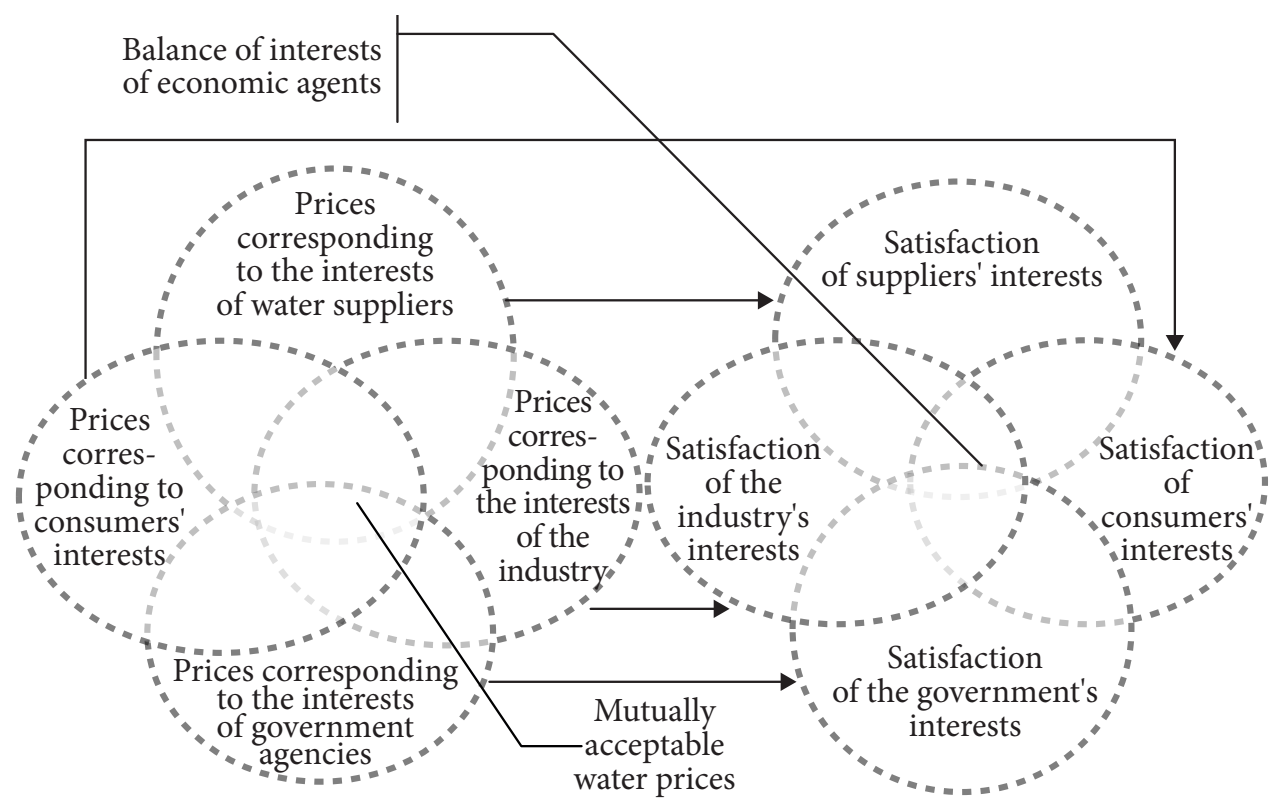

Figure 2. Balance of interests of economic agents in a regional water market Source: compiled by the authors

The incremental model of management should be implemented in several stages:

1. Goal-setting, which should take into account the need for rational distribution of water resources and efficiency of their use.

2. Planning, development of a uniform strategy of development aligned with the target indicators used for regions' socio-economic development strategies.

3. Analysis, collection and systematization of the data through monitoring of the key parameters. Decision-making based on monitoring of the target parameters.

5. Goal evaluation.

Figure 1 illustrates the application of the incremental model in relation to regional water markets. It should be noted that an important factor in the realization of this model is to provide sufficient information support for decision-making at each stage.

To assess the sufficiency of the hydropower sector's potential for the targets of regional development, we propose to use water-retaining capacity (WRC) and the index of industrial production (statistical indicator). The water-retaining capacity of gross regional product (GRP) can be used to detect trends of water use by looking at the dynamics of fresh water consumption. "The water-retaining capacity of a product is the generalized macroeconomic characteristic reflecting all climatic, social and economic and production changes in water infrastructure in the dynamics and the interfaced industries of activity" (Rybkina, 2015).

The WRC characterizes the rationality of water consumption:

$$
\mathrm{WRC}=\frac{\sum\left(V_{\mathrm{cB}_{i}}+V_{\Pi_{i}}\right)}{\mathrm{GRP}},
$$

$W_{R} C_{e}$ is the water-retaining capacity of GRP, $\mathrm{m}^{3}$, rub.; $V_{\mathrm{CB}_{i}}$ is the volume of fresh water consumption in the i-th industry, $\mathrm{m}^{3} ; V_{\pi_{i}}$ is the volume of consumption of cooling and reusable water in $i-y$ of the industry, $\mathrm{m}^{3}$.

One of important stages in the implementation of the above-shown incremental management model is goal evaluation, which can be carried out with the help of correlation-regression analysis. Thus, we will be able to assess the relationship between the GRP water capacity $(X)$ and the industrial production index of regions in the Southern Federal District $(Y)$. Since the assessment is made between the two parameters (factorial and resulting), the method of paired regression is used. The estimated regression equation looks the following way:

$$
y=b x+a+\varepsilon,
$$

$a$ and $b$ are the parameters of the model, $\varepsilon$ is the accidental deviation.

The parameters of the regression equation are determined by the least squares method, which 
allows us to obtain unbiased estimates. The system of normal equations is as follows:

$$
\left\{\begin{array}{l}
a n+b \sum x=\sum y \\
a \sum x+b \sum x^{2}=\sum y x
\end{array} .\right.
$$

In accordance with the algorithm for assessing the connection, after obtaining the parameters of the regression equation, we calculate the linear correlation coefficient, ranging within the interval $[-1 ; 1]$. The results will be interpreted in accordance with the Chaddock scale (see Table 1).

Table 1

\section{Quality standard of the correlation between} the parameters on the Chaddok's scale

\begin{tabular}{|c|c|}
\hline Correlation coefficient & Correlation \\
\hline $0.1 \leq r_{x y} \leq 0.3$ & Weak \\
\hline $0.3 \leq r_{x y} \leq 0.5$ & Moderate \\
\hline $0.5 \leq r_{x y} \leq 0.7$ & Noticeable \\
\hline $0.7 \leq r_{x y} \leq 0.9$ & Close \\
\hline $0.9 \leq r_{x y} \leq 1.0$ & High \\
\hline
\end{tabular}

Source: Compiled by the authors by using the data from Regions of Russia. Socio-Economic Indicators. 2019 (Accessed: 15.12.2020)

Thus, we assessed the relationship between the GRP water capacity and the industrial production index of the Southern Federal District. The data were obtained from the Federal State Statistics Service. We used the general statistical data to make a sample in accordance with the goals of this study, the incremental model, which made it possible to formulate accurate and reliable conclusions. In the above formulas, the following designations are used: $x$ is the industrial production index; $y$ is the water capacity of GRP. The equations of regression and ten coefficient of correlation calculated for each region and the nature of the relationship between the parameters according to the Chaddok's scale are presented in Table 2 . The graphic interpretation of the results is presented in Figures 3-8.

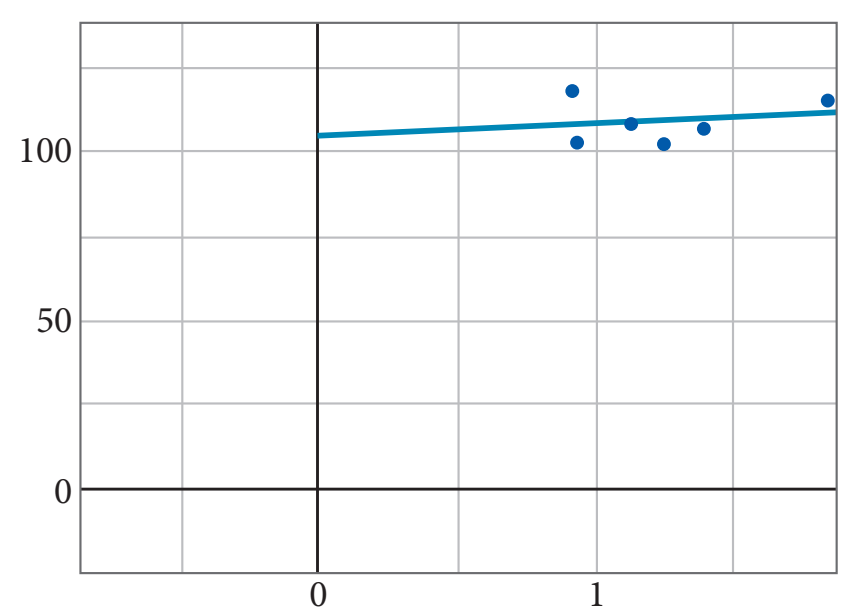

Figure 3. Chart of dispersion and schedule of the equation of regression - Adygea

Source: Compiled by the authors by using the data from Regions of Russia. Socio-Economic Indicators. 2019 (Accessed: 15.12.2020)

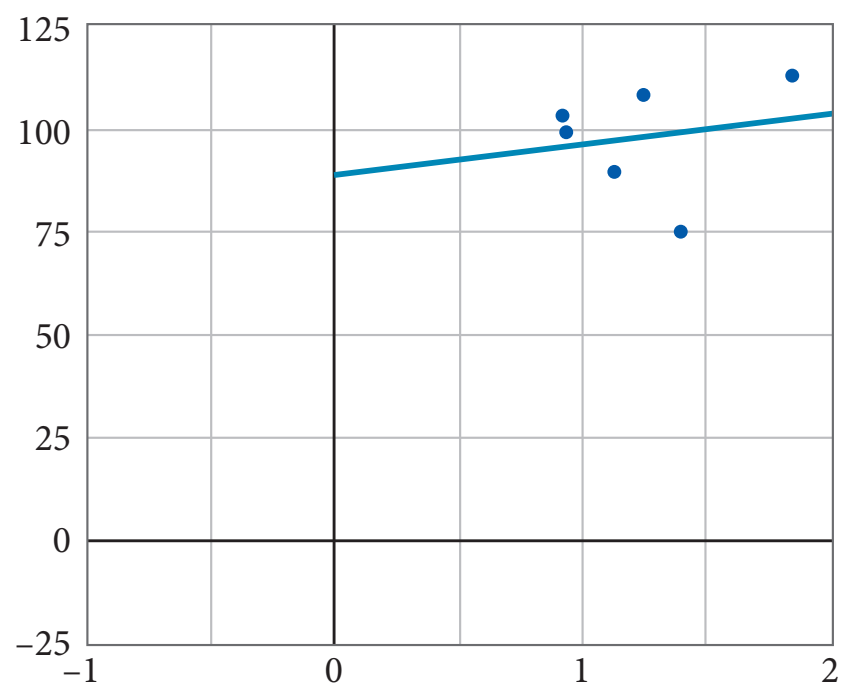

Figure 4. Chart of dispersion and schedule of the equation of regression - Kalmykia

Source: Compiled by the authors by using the data from Regions of Russia. Socio-Economic Indicators. 2019 (Accessed: 15.12.2020)

Table 2

Results of the economical and statistical analysis of the correlation between the water-retaining capacity of GRP and the index of industrial production

\begin{tabular}{|l|c|c|c|}
\hline \multicolumn{1}{|c|}{ Regions } & $\begin{array}{c}\text { Equation of linear } \\
\text { regression }\end{array}$ & $\begin{array}{c}\text { Value of coefficient } \\
\text { of correlation } \boldsymbol{r}_{\boldsymbol{x} y}\end{array}$ & $\begin{array}{c}\text { Correlation between } \\
\text { the parameters }\end{array}$ \\
\hline Republic of Adygea & $y=3.70 x+104.62$ & 0.20 & Weak \\
\hline Republic of Kalmykia & $y=7.46 x+89.01$ & 0.18 & Weak \\
\hline Krasnodar region & $y=3.06 x+102.02$ & 0.53 & Noticeable \\
\hline Astrakhan region & $y=1.75 x+108.92$ & 0.09 & Weak \\
\hline Volgograd region & $y=4.55 x+100.15$ & 0.80 & Close \\
\hline Rostov region & $y=4.28 x+104.70$ & 0.49 & Moderate \\
\hline
\end{tabular}

Source: Compiled by the authors by using the data from Regions of Russia. Socio-Economic Indicators. 2019 (Accessed: 15.12.2020). Retrieved from https://rosstat.gov.ru/folder/210/document/13204 


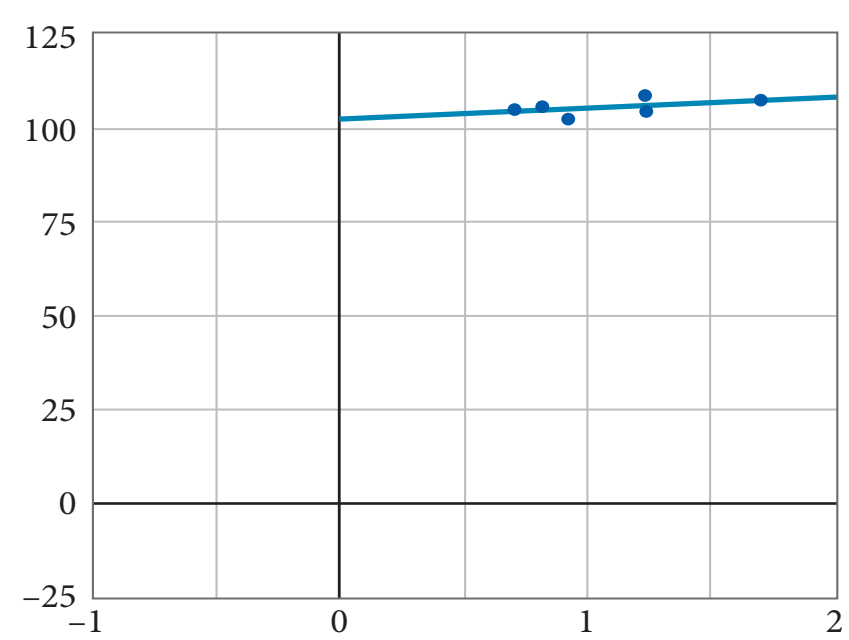

Figure 5. Chart of dispersion and schedule of the equation of regression - Krasnodar region

Source: Compiled by the authors by using the data from Regions of Russia. Socio-Economic Indicators. 2019 (Accessed: 15.12.2020)

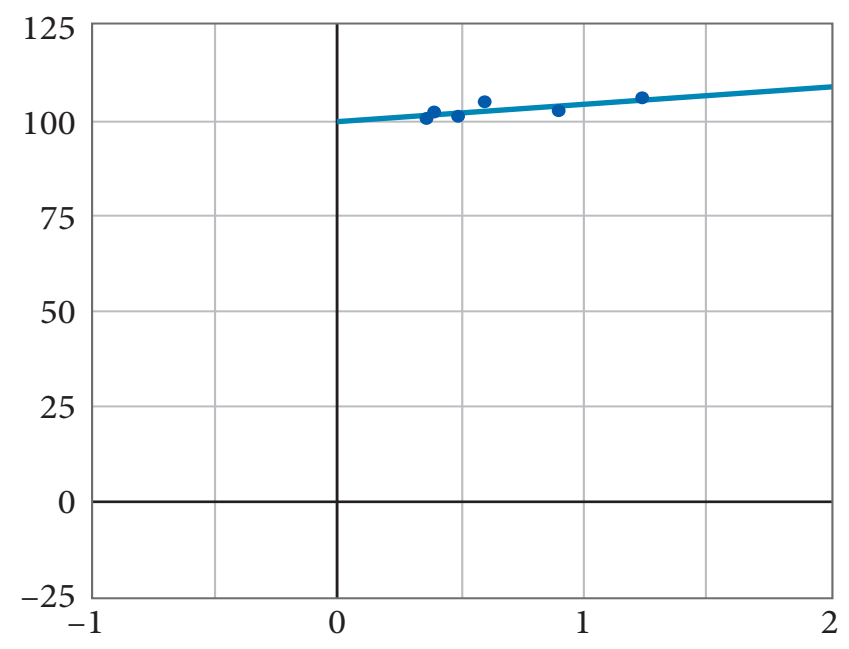

Figure 7. Chart of dispersion and schedule of the equation of regression -Volgograd region

Source: Compiled by the authors by using the data from Regions of Russia. Socio-Economic Indicators. 2019 (Accessed: 15.12.2020)

The results show that there is a connection between the water-retaining capacity of GRP and indexes of industrial production of regions: for example, it is noticeable for Krasnodar region; moderate, for Rostov region; and close, for Volgograd region.

\section{Discussion}

At the same time specialization of the region and the level of its industrial development influence water consumption. It is, therefore, necessary to consider the relationship between

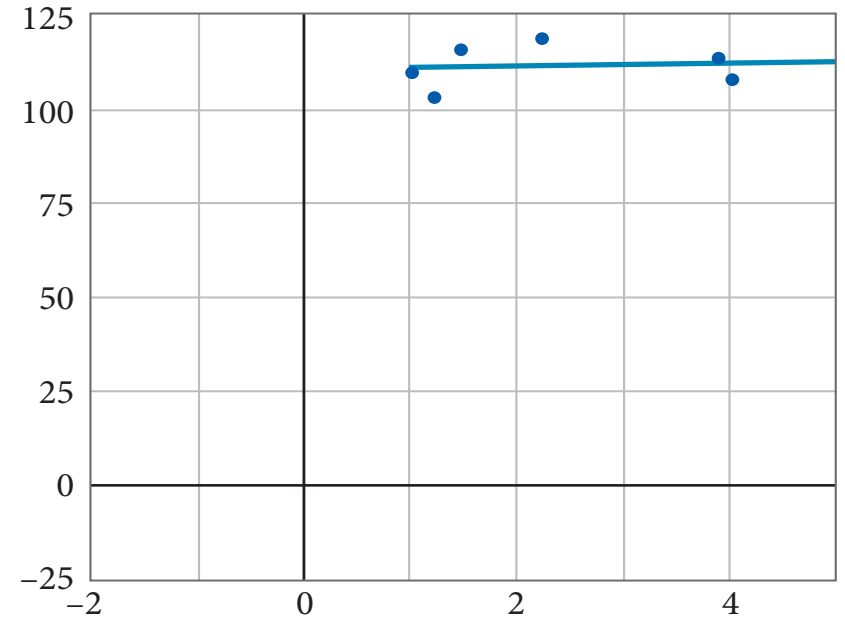

Figure 6. Chart of dispersion and schedule of the equation of regression - Astrakhan region

Source: Compiled by the authors by using the data from Regions of Russia. Socio-Economic Indicators. 2019 (Accessed: 15.12.2020)

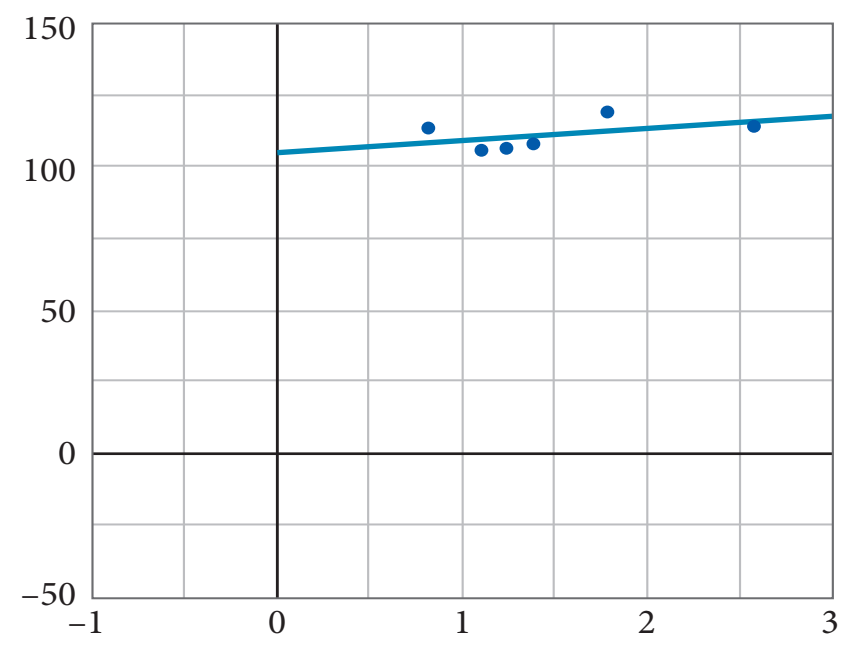

Figure 8. Chart of dispersion and schedule of the equation of regression-Rostov region

Source: Compiled by the authors by using the data from Regions of Russia. Socio-Economic Indicators. 2019 (Accessed: 15.12.2020)

the given parameters in relation to each region's specialization (Fig. 3-8).

Table 3 shows the correlations between the regions' water-retaining capacity of GRP and the index of industrial production and the types of these regions in accordance with the classification proposed by Grigoriev and his colleagues (Grigoriev et al., 2014). The official division of Russian regions into federal districts in combination with the classification means that the regions are divided into four large groups depending on their level of development and 
specialization: highly developed regions (financial and economic centers, regions specializing in exports of raw materials); developed regions (with a diversified economy, developed manufacturing sector, regions relying on extractive industry); moderately developed (in Grigoriev's terminology "industrial-agricultural" and "agricultural-industrial") and lagging regions (lagging-agricultural, lagging with the specialization on raw materials).

Comparison of the correlation between the water-retaining capacity of GRP and the index of industrial production of the regions and their development

\begin{tabular}{|l|l|l|l|}
\hline \multicolumn{1}{|c|}{ Regions } & $\begin{array}{l}\text { Correlation } \\
\text { between the } \\
\text { parameters }\end{array}$ & $\begin{array}{l}\text { Group of } \\
\text { regions }\end{array}$ & \multicolumn{1}{|c|}{ Region type } \\
\hline $\begin{array}{l}\text { Republic } \\
\text { of Adygea }\end{array}$ & Weak & Lagging & Lagging agrarian \\
\hline $\begin{array}{l}\text { Republic } \\
\text { of Kalmykia }\end{array}$ & Weak & Lagging & Lagging agrarian \\
\hline $\begin{array}{l}\text { Krasnodar } \\
\text { region }\end{array}$ & Noticeable & $\begin{array}{l}\text { Moderately } \\
\text { developed }\end{array}$ & $\begin{array}{l}\text { Agrarian and } \\
\text { industrial }\end{array}$ \\
\hline $\begin{array}{l}\text { Astrakhan } \\
\text { region }\end{array}$ & Weak & $\begin{array}{l}\text { Moderately } \\
\text { developed }\end{array}$ & $\begin{array}{l}\text { Agrarian and } \\
\text { industrial }\end{array}$ \\
\hline $\begin{array}{l}\text { Volgograd } \\
\text { region }\end{array}$ & Close & $\begin{array}{l}\text { Moderately } \\
\text { developed }\end{array}$ & $\begin{array}{l}\text { Agrarian and } \\
\text { industrial }\end{array}$ \\
\hline $\begin{array}{l}\text { Rostov } \\
\text { region }\end{array}$ & Moderate & Developed & $\begin{array}{l}\text { With diversified } \\
\text { economy }\end{array}$ \\
\hline
\end{tabular}

Source: Compiled by the authors by using the data from Regions of Russia. Socio-Economic Indicators. 2019 (Accessed: 15.12.2020). Retrieved from https://rosstat.gov.ru/folder/210/ document/13204

Our analysis of the relationship between the GRP water capacity, the index of industrial production and the level of development of the given regions has led us to the following conclusions. Regions of the Southern Federal District with a weak correlation between the parameters under study tend to belong to the groups of lagging regions, with the exception of Astrakhan region, which qualifies as a moderately developed region. In the groups of regions characterized as moderately developed or developed, the relationship between the parameters is confirmed, and they generally have a vigorous manufacturing sector (Krasnodar region, Volgograd region and Rostov region). It should be noted that despite the fact that Astrakhan region belongs to the group of moderately developed regions, the structure of its GRP is dominated by a less water-intensive type of activity - agriculture, forestry, hunting, fishing and fish farming.

Thus, the results of our analysis confirm our initial hypothesis about the influence of the GRP water capacity on the specialization and development of regions.

\section{Conclusion}

The prospects of development of water management in regions are associated with ensuring the balance of interests of the water market's participants. The program-modular approach proposed by the authors combines the administrative and resource potential of regional water management and aligns the goals on the regional level with the more general goals of hydropower modernization. Since the development of regional economies depends not only on the amount but also on specific characteristics of water consumption, what comes to the fore is zoning of the interests of the participants of regional water markets.

The novelty of our research is that it relies on the incremental model, which, unlike other models of management, leads to an incremental achievement of the desired through certain iterations. Thus, we have managed to show various types of connection between the level of water-retaining capacity of GRP and indexes of industrial production for southern regions of Russia. These regions are the centers of industrial production of the Southern Federal District. Some of them can be described as developed (Rostov region) and moderately developed (Krasnodar and Volgograd regions), according to the classification proposed by Grigoriev et al. (2014). Rostov region belongs to the group of regions with a diversified economy, which means that it has a broad range of economic activities, while Volgograd region and Krasnodar regions can be classified as agrarian and industrial regions. This confirms our initial hypothesis that the water-retaining capacity of GRP affects regional specialization. We have found a close connection between water-retaining capacity and industrial production for the three above-mentioned regions. Our findings can be used to improve the incremental model of water management in regions.

\section{References}

1. Calizayar, A., Meixner, O., Bengtsson, L., \& Berndtsson, R. (2010). Multi-criteria Decision Analysis (MCDA) for Integrated Water Resources Management (IWRM) in the Lake Poopo Basin, Bolivia. Water Resources Management, 24(10), 2267-2289. doi: 10.1007/s11269-009-9551-x 
2. Danyang Di, Zening Wu, Huiliang Wang, \& Cuimei Lv (2020). A Double-Layer Dynamic Differential Game Model for the Optimal Trading Quantity of Water and Price Setting in Water Rights Transactions. Water Resources Management, 34(1), 245-262.

3. Delorit, J.D. Parker, D.P., \& Block, P.J. (2019). An agro-economic approach to framing perennial farm-scale water resources demand management for water rights markets. Agricultural Water Management, 218(C), 68-81.

4. Golyashev, A.V., Grigoriev, L.M. (2014). Types of Russian regions: stability and shifts in 2003-2013. Retrieved from http://ac.gov.ru/files/publication/a/4363.pdf (In Russ.)

5. Hmaed Najafi Alamdarlo, Fariba Riyahi, \& Mohamad Hasan Vakilpoor (2019). Wheat Self-Sufficiency, Water Restriction and Virtual Water Trade in Iran. Networks and Spatial Economics, 19(2), 503-520. doi: 10.1007/s11067-018-9383-4

6. Idziev, G.I. (2011). Using the program-target method in the formation of the industrial policy of the Republic of Dagestan. Regionalnaya ekonomika: teoriya i praktika = Regional Economics: Theory and Practice, 24(297), 22-27. (In Russ.)

7. Kosolapov, A.E., Kosolapova, N.A., Matveeva, L.G., \& Chernova, O.A. (2018). Efficiency of water resource use in economics of the North Caucasus mountain territories. Ustojchivoe razvitie gornyx territorij = Sustainable Development of Mountain Territories, 10(1), 48-62. (In Russ.)

8. Levit-Gurevich, L.K., Pryazhinskaya, V.F., Khranovich, I.L., Yaroshevsky, D.M. (2010). Problems when making schemes for the integrated use and conservation of water bodies. Vodnoe xozyajstvo Rossii = Water economic of Russia, 6, 4-16. (In Russ.)

9. Lindblom, C.E. (1959). The Science of Muddling Through. Public Administration Review, 19(2), 79-88.

10. Loukas, A., Mylopoulos, N., \& Vasiliades, L. (2007). A Modeling System for the Evaluation of Water Resources Management Strategies in Thessaly, Greece. Water Resources Management, 21(10), 1673-1702. doi: 10.1007/s11269-006-9120-5.

11. Matchaya, G., Nhamo, L., Nhlengethwa, S., \& Nhemachena, Ch. (2019). An overview of water markets in southern Africa: an option for water management in times of scarcity. International Water Management Institute, 11(5), 1-16.

12. Matveeva, L.G., Chernova, O.A., Kosolapova, N.A., \& Kosolapov, A.E. (2018). Assessment of water resources use efficiency based on the grp water intensity indicator. Regional Statistics, 8(2), 154-169.

13. Matveeva, L.G., Chernova, O.A., \& Kosolapova, N.A. (2020). Pricing Problems in the Competitive Environment of Water-Economic Complex in the Region. Zhurnal Economicheskoj Teorii = Russian Journal of Economic Theory, 17(2), 424-432. (In Russ.) doi: 10.31063/2073-6517/2020.17-2.15

14. Mitrofanova, I.V. (2006). Program-targeted approach to the management of the territory: an analysis of modern domestic experience. Regionalnaya ekonomika: teoriya $i$ praktika $=$ Regional Economics: Theory and Practice, 6, 32-38. (In Russ.)

15. Nazemi, N., Foley, R.W., Louis, G, \& Keeler, L.W. (2020). Divergent agricultural water governance scenarios: The case of Zayanderud basin, Iran. Agricultural Water Management, 229(C). doi: 10.1016/j.agwat.2019.105921

16. Nikitaeva, A.Yu., \& Aleshin, A.V. (2013). The conceptual model of inter-firm partnership for solving actual problems and modernizing the economy of the regions of the South of Russia. Journal of Economic Regulation, 4(4), 34-40. (In Russ.)

17. Niua, G., Li, Y. P..Huangb, G. H., Liu, J., \& Fanb, Y. R. (2016). Crop planning and water resource allocation for sustainable development of an irrigation region in China under multiple uncertainties. Agricultural Water Management, 166, 53-69. doi: 10.1016/j.agwat.2015.12.011

18. Polyakova, Yu.N., \& Shevchenko, I.K. (2017). Software technology management complex interdisciplinary research in educational organizations. Upravlenie universitetom $=$ University management: practice and analysis, 1(107), 80-87. (In Russ.)

19. Rybkina, I.D. (2015). Comparative analysis of the efficiency of water use in the regions of Western Siberia in comparison with the all-Russian and Western European levels. Vodnoe khozyaistvo Rossii = Water Economy of Russia, 3, 80-88. (In Russ.)

20. Shevchenko, I.K. (2009). Software and project tools to support the process of management of economic systems: theory, methodology, implementation technology (pp. 226-229). Taganrog: Publishing house TTI SFU. (In Russ.) 
21. Suratin Aloysius, Triakuntini Eka \& Herdiansyah Herdis (2019). Effects of the implementation of a progressive tariffs policy on water management in DKI Jakarta, Indonesia. Environmental \& Socio-economic Studies, Sciendo, 7(4), 36-44.

22. Tikhomirova, O., \& Vinogradov, I. (2007). Regulation in the Energy Sector: a CustomerOriented Approach and Protection of the Economic Interests of the RSK. Energeticheskij rynok = Energy Market, 8, 43-51. (In Russ.)

23. Torregrosa, T., Sevilla, M., Montaño, B., López-Vico, V. (2010). The Integrated Management of Water Resources in Marina Baja (Alicante, Spain). A Simultaneous Equation Model. Water Resources Management, 24(14), 3799-3815. doi: 10.1007/s11269-010-9634-8

24. Xu, C.-Y., \& Singh, V. P. (2004). Review on Regional Water Resources Assessment Models under Stationary and Changing Climate. Water Resources Management, 18(6), 591-612. doi: 10.1007/ $\underline{\text { s11269-004-9130-0 }}$

25. Zhang, D., \& Guo, P. (2016). Integrated agriculture water management optimization model for water saving potential analysis. Agricultural Water Management, 170, 5-19. doi: 10.1016/j.agwat.2015.11.004

\section{Information about the authors}

Lyudmila G. Matveeva - Doctor of Economics, Professor, Department of Information Economics, Southern Federal University, Russian Information Analytical and Scientific Research Water Management Center (88 Gorky street, Rostov-on-Don, 344002, Russia); e-mail: matveeva_lg@mail.ru.

Olga A. Chernova - Doctor of Economics, Professor, Department of Information Economics, Southern Federal University, Russian Information Analytical and Scientific Research Water Management Center (88 Gorky street, Rostov-on-Don, 344002, Russia);e-mail: chernova.olga71@yandex.ru.

Ekaterina V. Kaplyuk - Cand. Sc. (Econ.), senior researcher, Research Center «Instrumental, Mathematical and Intellectual Support of Economy», Southern Federal University (44 Neksovsky street, Taganrog, 347922, Russia); e-mail: ekapluk@gmail.com.

ARTICLE INFO: received January 17, 2021; accepted March 4, 2021

\section{Информация об авторах}

Матвеева Людмила Григорьевна - доктор экономических наук, профессор кафедры информационной экономики экономического факультета, Южный федеральный университет, ведущий научный сотрудник, Российский информационно-аналитический и научноисследовательский водохозяйственный центр (344002, г. Ростов-на-Дону, ул. Горького, 88); e-mail: matveeva_lg@mail.ru.

Чернова Ольга Анатольевна - доктор экономических наук, профессор, профессор кафедры информационной экономики экономического факультета, Южный федеральный университет, старший научный сотрудник, Российский информационно-аналитический и научно-исследовательский водохозяйственный центр (344002, г. Ростов-на-Дону, ул. Горького, 88); e-mail: chernova.olga71@yandex.ru.

Каплюк Екатерина Валерьевна - кандидат экономических наук, старший научный сотрудник Центра научных исследований «Инструментальные, математические и интеллектуальные средства в экономике», Южный федеральный университет, (347922, г. Таганрог, пер. Некрасовский, 44); e-mail: ekapluk@gmail.com.

ИНФОРМАЦИЯ О СТАТЬЕ: дата поступления 17 января 2021 г.; дата принятия к печати 4 марта 2021 г. 